\title{
Timely loss recognition in Brazilian firms under corruption investigation ${ }^{\star}$
}

\author{
Silvia Pereira da Rocha ${ }^{1}$ \\ (D) https://orcid.org/0000-0002-8778-683X \\ Email: sprochabr@gmail.com \\ Francisco Antonio Bezerra ${ }^{1}$ \\ (D) https://orcid.org/0000-0002-0427-8742 \\ Email: francisco@fucape.br
}

${ }^{1}$ Fucape Business School, Departamento de Contabilidade e Finanças, Vitória, ES, Brazil

Received on 09.17.2019 - Desk acceptance on 10.14.2019 - 4th version approved on 09.11.2020

Editor-in-chief: Fábio Frezatti

Associate Editor: Eliseu Martins

\begin{abstract}
This article evaluates the impact of the disclosure of the participation of Brazilian firms listed on the Bolsa Brasil Balcão (B3) in corruption scandals through media scrutiny and by disclosure of independent auditors on the quality of accounting information, measured from the perspective of accounting conservatism. We examine the possible theoretical link between the disclosure of corruption scandals and the quality of accounting information in the Brazilian context. Brazil has gone through successive corruption scandals involving firms and government entities in different levels. Accounting can be an important tool to mitigate said risks based on the artifacts it has to inform key stakeholders. However, it is necessary to identify the extent to which these artifacts can be influenced by the actors involved in these scandals. The research places accounting as an instrument subject to pressures from different interests and that may be shaped to them. Although accounting is an instrument that must aim to reduce information asymmetry, preventing the harmful effects of corruption, in specific contexts, it can be used in the opposite direction, such as in cases of corruption and economic crises. We used the model based on Ball and Shivakumar (2005) with specific modeling characteristics for corruption and crisis. The models were estimated using the Stata 13 software using the pooled approach using the Ordinary Least Squares (OLS) estimation method, clustered by year and economic sector, and the Generalized Least Squares (GSL) estimator. The results point to the presence of conservatism when disclosing involvement in investigations of corruption crimes in Brazil. This behavior was less intense in firms effectively mentioned in these events. These results highlight the relevance of studies aimed at clarifying the connections between corruption and accounting reports, enabling the development of measures to curb corruption in the business environment.
\end{abstract}

Keywords: quality of accounting information, timely loss recognition, corruption.

Correspondence address

Silvia Pereira da Rocha

Fucape Business School, Departamento de Contabilidade e Finanças

Avenida Fernando Ferrari, 1358 - CEP 29075-505

Boa Vista - Vitória - ES - Brazil

* Paper presented at the 6th International Conference on Management Studies (ICMS 2020), Dubai, United Arab Emirates, April 2020. 


\section{INTRODUCTION}

In this paper, we evaluated whether the greater scrutiny of the national media and the records in independent auditor's reports about the involvement of Brazilian firms listed on the B3 - Brazil Stock Exchange and Over-theCounter Market in corruption scandals is able to change the behavior of the level of accounting conservatism, measured for the timely loss recognition, from 2010 to 2016.

In principle, one could imagine that the existence of a significant association between political entities and public companies would imply greater transparency in reporting the results of these firms, whether for legal reasons due to the inspection of government entities, or even due to media scrutiny. In other words, a high level of compliance with current accounting standards and better Quality of Accounting Information (QAI) would be expected. However, the studies by Chaney et al. (2010) concluded the opposite.

Chaney et al. (2010) state that there are at least three explanations for understanding this relationship differently. The first explanation is the financial benefit from relations with political entities, which act as an incentive for managers to hide, hinder, or be less transparent in these transactions to the detriment of investors' interests. In Brazil, this takes on even more complicated aspects of observation and control, due to difficulties in the investigation and verification of illicit processes. Dowbor (2012) developed a very critical description of the paths of corruption in Brazil and showed how the sophistication of political connections combined with even more sophisticated financial processes allows the manipulation of information and the impunity of those involved in illegal acts.

The second explanation offered by Chaney et al. (2010) refers to the strength of the political connection that may provide a certain level of protection for connected firms, which would be exempt from punishment by inspection bodies and, thus, unconcerned about achieving better levels of QAI. In Brazil, this phenomenon was observed by Pinheiro et al. (2016), who stated that political and democratic stability could discourage the harm caused by political connections by generating more costs than benefits. However, the authors observed that in developing economies, due to the difficulty in raising funds and reducing risks and uncertainties, firms may seek political connections as a solution. Pletsch et al. (2018) proved that in Brazil the political connection is capable of reducing the cost of debt financing for public companies.
The third explanation presented by Chaney et al. (2010) is that firms with poor earnings quality are more likely to establish political connections. This would result in a strong correlation between a political connection and a lower QAI. This research follows the findings of Chaney et al. (2010), as it evaluates whether a specific incentive (scrutiny by the media and records in independent auditor's reports disclosing the involvement of firms in corruption investigations) can increase the conservatism of the accounting information of firms with shares traded on $\mathrm{B} 3$. As a proxy for this incentive to change behavior, we used data that related publicly traded Brazilian companies to investigations of involvement in corruption crimes that had repercussions in the national media, as well as those recorded in the reports of independent auditors.

The study by Malagueño et al. (2010) analyzed the relationship between QAI and corruption and, among other conclusions, established that those countries that have effective regulation and judiciary, as well as a higher number of firms that hire independent auditors classified in the group of the four largest international accounting firms, the Big Four, besides of being better positioned in the Global Competitiveness ranking prepared by the World Economic Forum (Global Competitiveness Report), present better QAI and, thus, tend to be less corrupt.

It is clear that, in addition to the external dimension (politics, the effectiveness of the control made by democratic institutions) in which firms find themselves, some internal decisions or incentives hampers the analysis on this issue and the impact that it may have on the QAI. In this regard, we delimited the methodological procedure in an attempt to cover part of this problem.

From the perspective of the Agency Theory (Jensen \& Meckling, 1976), the higher the level of QAI, the greater the limitation of the agent's harmful behavior in its decisions (Antunes \& Mendonça, 2008). In this research, we use timely loss recognition as a proxy for QAI, since it is commonly classified in the literature as a characteristic of conservatism. As interpreted by Basu (1997), conservatism represents the accounting's demand for greater verification requirements for recording good news than bad news. In the same direction, Watts (2003) conceptualizes conservatism as the asymmetric verification requirements for gain and losses records defined here as any information that increases the profits reported by the firms (gains) or, on the other hand, that reduces that reported amount (losses). 
Malagueño et al. (2010) found that the more QAI the greater the perception that the firm operates transparently, mitigating risks of involvement in corrupt practices, among other situations that can be detrimental to its results.

The interaction between timely loss recognition and the disclosure of the involvement of firms in investigations of corruption crimes has not been empirically examined in previous literature. Thus, here we investigate whether the media disclosure and the records from independent audit reports regarding the involvement of Brazilian firms in corruption crimes investigations increase the timely loss recognition.

The goal of this study is to assess whether a specific incentive (media scrutiny and records in independent audit reports) is able to change the behavior described by Chaney et al. (2010) in which managers are led to hide or be less transparent in situations of loss recognition. For this reason, we chose a proxy related to the accounting disclosure of a transaction (timely loss recognition).

The study further assesses the importance of QAI, given its use as a way to mitigate risks of involvement of firms in corruption crimes and for collaborating with the disclosure of the impact that the media and independent audit reports have on QAI in Brazil, focusing particularly on corruption scandals.

The results of this research indicate that media events and the independent auditor's records can be associated with the increase in the timely loss recognition and that, for the firms effectively mentioned, such behavior was recorded with less intensity. Besides, for these firms, such timely loss recognitions appears to be much more strongly affected by periods of crisis than by the exposure by the media.

\section{THEORETICAL FRAMEWORK}

\subsection{Timely Loss Recognition}

From the perspective of agency problems, QAI refers to how useful accounting can act as a mechanism to prevent the expropriation of resources from capital suppliers (Defond \& Zhang, 2014).

Yoon (2007) and Chen et al. (2010) defined the QAI based on its adequacy to basic accounting concepts and the way it represents the firm's results and must reflect faithfully its economic situation. The authors, in their respective studies, clarified that the attributes of QAI assessment are: (i) accrual quality; (ii) persistence; (iii) predictability; (iv) smoothness; (v) reliability; (vi) relevance; (vii) timeliness; and (viii) conservatism.

Specifically, regarding conservatism, Feltham and Ohlson (1995) conceptualized it as the difference between the firm's book value (which tends to recognize new information with prudence) and the firm's market value (including the expected value and the opportunity for growth). When the book value is less than the market value (that is, the market-to-book indicator is greater than 1), it means that the financial statements showed a certain level of conservatism.

The concept of conservatism developed by Watts (2003) concerns the difference required in the intensity of verifications to recognize expenses and revenues in accounting reports, due to the need for more robust (verifiable) contractual accounting metrics. This concept agrees with the studies by Basu (1997) and Ball and Shivakumar (2005). Basu's (1997) interpretation of accounting conservatism was that it had an asymmetric recognition, by accounting, of good news in relation to bad news. Thus, losses are recognized more opportunely, albeit with low verification, and are more likely to be recognized in the current period. Therefore, firms with negative returns (losses) in the current period tend to reverse this result in the following period (if the negative events are not confirmed or present themselves with less intensity), while, for the recognition of gains or other revenues, a higher level of verification is required. Firms with positive returns (profit) in the current period would tend to obtain positive results in the following period in a situation of high conservatism.

While maintaining the definition given by Basu (1997) for conservatism, Ball and Shivakumar (2005) stated that conservatism can be classified as conditional - when the anticipation of the record is related to the risk of economic loss, generating an asymmetry between the recognition of good and bad news, favoring the latter - or unconditional - when two equally valid options are evaluated and the one with the lowest profit and the lowest net equity is chosen. Ball and Shivakumar (2005) analyzed the timely loss recognition in English public and private companies, by accounting for accruals, and concluded that revisions to future cash flow expectations are recognized in current results through accruals, that is, accruals are positively 
related to revisions in future cash flow expectations, and will be greater in the event of losses.

We adopted for this research the model of early loss recognition, developed by Ball and Shivakumar (2005), since it takes into account that bad news (for example: disclosure of firm involvement in corruption) is recorded as expenses as soon as they occur (not in future periods) and that such losses are transitory components of the result, that is, they are not persistent. The model is presented in Equation 1 below:

$$
\Delta N I_{t}=\alpha_{0}+\alpha_{1} \Delta D N I_{i t-1}+\alpha_{2} \Delta N I_{i t-1}+\alpha_{3}\left(\Delta D N I_{i t-1} * \Delta N I_{i t-1}\right)+\varepsilon_{i t}
$$

in which $\Delta N I_{t}$ represents the profit variation between the period $t-1$ and $t ; \Delta D N I_{i t-1}$ is a binary variable that receives the value 1 (one) for negative variations in the previous year's profit and 0 (zero) for positive variations; $\Delta N I_{i t-1}$ represents the profit variation from the period $t-2$ to $t-1$; and $\left(\Delta D N I_{i t-1}{ }^{*} \Delta N I_{i t-1}\right)$ is the interaction variable for negative variations in profit.

According to Moreira (2009), in this model negative coefficients indicate that there was a reversal of profits. If the coefficients are positive, they indicate that the persistent profit components have not been reversed and will be negative, otherwise. The coefficient $\alpha_{2}$ indicates the profit response when the return is positive. Thus, it is expected to be positive and zero, indicating that there was a deferral of the recognition of gains until the moment when the cash flow is performed, and, in this case, the gain situation becomes a persistent component in the profit. On the other hand, if $\alpha_{2}$ is negative, there is a timely gain recognition. The $\alpha_{3}$ coefficient is related to the recognition of losses, therefore, a value less than zero indicates the timing of the recognition of bad news. The sum of the coefficients $\alpha_{2}+\alpha_{3}$ captures the full effect of the timely recognition of good and bad news. It is estimated that this sum must be less than zero, indicating that there was a timely loss recognition, that is, there were transitory decreases in the results that may be reversed in the subsequent period.

The influence of the scrutiny of the media under the conservatism of independent auditors pre- and postSOX was pointed out by Feldmann and Read (2010), who analyzed a sample composed of American firms that declared bankruptcy in the period from 2000 to 2007. As a result of the study, they concluded that in the period 2002-2003 (post-SOX), there was a greater number of independent audit reports informing risks of going concern when compared to the period 2000-2001 (preSOX), mainly due to media scrutiny. Additionally, they found that, in subsequent periods (2004 onwards), the number of reports informing risks involving going concern was reduced to the same pre-SOX level.

From another perspective, the economic environment is considered important to control the level of conservatism decision, as can be seen in the work developed by Beams and Yan (2015) who concluded that, due to the 2008 financial crisis, there was an increase in the conservatism of the independent auditors, through the issuance of audit reports warning about the going concern, mainly, for that group of firms with financial difficulties.

\subsection{Corruption Analysis Perspective}

Kaufmann (2015) argues that corruption involves a network of politicians, organizations, firms, and private individuals who conspire to benefit from access to power, public resources, and politics to the detriment of the public good.

With no pretense of exhausting the list of harmful effects of corruption, it is possible to mention a few: increased market risks and uncertainties, reduced and inefficient investments, reduced economic and social development, damage to competition, and inefficiency of the public and private sector ( Delavallade, 2006; Mauro, 1996; Nguedie, 2018; Rady, 2016; Shleifer \& Vishny, 1993).

In this sense, Shleifer and Vishny (1993) highlighted two reasons why corruption can be costly for the economic development of countries: (i) the weakness of the central government, which allows for increased bureaucracy and imposes bribes, which may prevent the continuation of a project and jeopardize investments; (ii) the need to keep the act of corruption a secret may preclude investments in important projects in the areas of health and education, to the detriment of potentially useless projects, such as in the areas of defense and infrastructure (if they present better opportunities for earnings).

La Porta et al. (2000) argued about the need to regulate the financial market and protect investors and exemplified with the models of regulation of the securities markets in the United States and Germany, which were successful and share a common element: the listed firms are required to fully disclose their financial information, as this is required by local regulatory bodies. Finally, La Porta et al. (2000) conclude that, although such disclosure is not enough by itself to guarantee the 
rights of shareholders and creditors, it can help them to protect themselves.

It is also worth mentioning the studies by Amaral and Santos (2017), which, when analyzing the effect on the share price of firms punished for corruption under the Foreign Corrupt Practices Act (FCPA), of 1977, resulting from the penalties imposed by the Securities and Exchange Commission (SEC, civil sphere) and the Department of Justice (DOJ, criminal sphere), identified that the abnormal returns were strongly adjusted negatively both on the day the punishment was announced and on the day after the event.

In general, corruption is understood, by developed countries, as an evil to be fought, since it can prevent free enterprise and hinder the strengthening of free competition. Therefore, actions around the world have been implemented to fight it, such as: the work of the Organization for Economic Cooperation and Development (OECD), in which the signatory countries have undertaken to create specific anti-corruption laws; the edition of the English anti-corruption law (UK Bribery), on April 8, 2010; and the edition of the Brazilian anticorruption Law (Law n. 12,846), on August 1, 2013 (Amaral \& Santos, 2017).

Some studies have been carried out in Brazil to describe the impact of corruption from different perspectives. In this sense, Sodré and Alves (2010) concluded that corruption is not directly related to the total amount received through amendments in favor of municipalities, but with the fact that it receives them regardless of the amount. Ferraz and Finan (2008) investigated the importance of transparency in Brazil and concluded that a Brazilian person, when well informed, can review his position about a candidate, especially if he has been related to some corruption act.

Ferraz et al. (2012) make a relationship between corruption and the quality of education and conclude that the education sector loses incentives and resources, especially teachers, who start to receive lower salaries and less training and also lower scores in national education assessments.

Caldas et al. (2016) investigated the relationship between the level of corruption and the composition of public spending and observed that, unlike other countries in Brazil, higher spending on education and health is positively related to the higher level of corruption, since Brazilian legislation establishes minimum investment amounts in the education sector compared to the total revenue collected, that is, there is an increase in expenses related to this area that are not necessarily reverted to improve the well-being of society.

\subsection{Quality of Accounting Information, Corruption, and the Timely Loss Recognition}

Accounting can play a significant role in the allocation of resources, in the risk calculation, in the management models, and in defining the terms of the debt contracts, since, these elements directly or indirectly end up interfering in the economic development of a country. Thus, an analysis of what can affect the generated QAI becomes relevant in any context (Chen et al., 2020).

For Riahi-Belkaoui (2004), the main threat to QAI would be the earnings opacity, which represents the variation between the numbers released by firms and those that would be the real ones, but which would be hidden, due to management decisions and accounting adjustments. For the author, the degree of earnings opacity arises from local pressures that also act as the main levers to change their behavior, making it clear that the level of corruption in a country is an important determinant of the level of earnings opacity.

Sargiacomo et al. (2015) assume that accounting and auditing have artifacts capable of identifying and suppressing acts of corruption. However, they believe that, in the same way, corrupt actors can compromise these artifacts in the generation of accounting information. The authors present how these acts can interfere in QAI, through a case study ("Operation Clean Hands", against corruption in Italy, 1992-2002), to question accountingbased anti-corruption policies. The authors conclude that although they believe in the potential that accounting has to prevent these situations, it is, on the other hand, influenced by corporate rules approved by those being or that might be investigated, which may allow them to block, or to determine the earnings opacity mentioned by Riahi-Belkaoui (2004).

Garcia and Teodósio (2020) analyzed the lessons of Italy (1990s) and Sweden (19th century) in facing corruption and drew a parallel with the Brazilian case, in which cases of corruption persist despite their public accounting and financial control systems. The authors state that Sweden's success is mainly due to losses resulting from the war with Russia (1808-1809), political and bureaucratic reforms in its institutions, the implementation of interaction controls with private interests, the establishment of new rules for the functioning of the State and the strong movement of civil society. They also considered that the situation in Italy is similar to that in Brazil since in both cases the beginning of the fight against corruption occurred with a part of the judiciary causing the confrontation. 
Both countries have limited control systems, already assimilated by systemic corruption and both societies are not very active in pressing for improvements in public governance. As a result, they suggest that the active role of civil society, in addition to robust accounting and control systems, is fundamental to fighting corruption.

Suzart (2012) investigated the importance of sociocultural aspects of a society on the level of disclosure of accounting information in 107 countries, taking into account the international convergence of accounting standards. One of the findings of the study shows that countries with high levels of bureaucracy and corruption have lower levels of disclosure of accounting information.

Santos and Takamatsu (2018) studied the effect of corruption in 20 emerging countries and the earnings opacity, as measured by earnings aggressiveness, loss aversion, and income smoothing. The results indicated that, in more corrupt countries, earnings have less informative power, with greater smoothing and greater aversion to losses.

Bhattacharya et al. (2003) state that QAI is the result of three main elements: (i) managerial motivation; (ii) accounting standards; and (iii) effective application of accounting standards (audit quality). Accounting information can be jeopardized due to some motivation that leads actors to manage results; as international accounting standards are based on general standards, there is the possibility of manipulating this information, or that such standards are insufficient to adequately monitor and portray an economic event. According to the authors, the difficulties emerge due to the complexity of extracting the motivations that are behind each manager.

Malagueño et al. (2010) identified the relationship between corruption and two QAI measures, the hiring of an independent auditor (Big Four) and the ranking of countries in the Global Competitiveness Report, prepared by the World Economic Forum. The authors concluded that the countries whose firms hired more independent auditors from the Big Four group of firms and which were also better positioned in the ranking had lower levels of perceived corruption.

Lara et al. (2009) discussed the impact of conservatism for QAI, with an investigation focused on the ability to reduce information asymmetry between shareholders (insiders) and other investors (outsiders). The results did not prove the increase in information asymmetry between different investors, on the contrary, it concluded that conservatism ends up being beneficial to all types of investors and other interested parties, such as capital lenders.

Accounting conservatism is a clear indication that bad news is incorporated into the result calculation before good news (Ball \& Shivakumar, 2005; Basu, 1997; Watts, 2003). In other words, conservatism leads to slower response of reported earnings to the occurrence of good news compared to bad news. Thus, the level of conservatism can have a significant impact on the profit reported by firms, defining to some extent their performance and, therefore, QAI (Basu, 1997).

In summary, accounting information is an important tool for the development of society, as it can act to limit corruption. However, studies demonstrate the possibility that accounting will suffer distortions and generate information that, instead of decreasing, may increase the information asymmetry between related parties and other stakeholders. Thus, the monitoring of QAI becomes relevant, especially from the perspective of conservatism, since it can reduce this asymmetry.

Sacramento and Pinho (2018, p. 120) state that:

even in formal democratic regimes, when values of selfexpression are relatively widespread, the population tends to protest against unpopular actions by political elites and to have the means to make their protests effective enough to influence the mass media to 'patrol the corruption of elites and show failure more closely?

The studies by Dhaliwal et al. (2017) confirmed the significant negative association between the issuance of a modified independent auditor's report in China and the negative coverage of its clients by the press, especially during the period when litigation risks are greatest.

Thus, considering the firm's involvement in corruption crimes and the fact that their disclosure fits as a negative fact (or bad news), we evaluated the following hypothesis (H1): the disclosure of the involvement of companies in investigations of corruption crimes increases the timely loss recognition.

This expectation is supported by the results of Beams and Yan (2015), who found that, due to the financial crisis of 2008, there was an increase in the conservatism of independent auditors through the issuance of audit reports warning about the going concern, especially for the group of firms with financial difficulties.

In this study, we also evaluated the impact of the financial crises from 2014 to 2016 on the timely loss recognition by publicly traded Brazilian companies, through the development of a complementary model, called the Crisis Model. 


\section{METHODOLOGY}

In this research, we used annual data from 327 Brazilian firms, publicly-held corporations that trade shares in B3, from $01 / 01 / 2010$ to $12 / 31 / 2016$, with an "active" registration status. We collected the accounting information in the Economática database and considered the consolidated balance sheets in December of each year. As the model uses variables from the previous period for scheduling, the data covers the period from 2009 to 2016. We adopted the following procedures for the composition of the final sample:

i. Firms with B3 registration status as "canceled" were excluded;

ii. Firms listed in the Brazilian Depositary Receipts (BDRs) segment were excluded, given that they represent securities issued in Brazil, but backed by shares of foreign firms. Thus, they are not subject to the same information disclosure rules as other Brazilian firms;

iii. Firms with operations in the financial sector, funds, or classified as "others" in Economática database were excluded, to avoid bias, specification problems in the model estimations (Paulo, Cavalcante \& Paulo, 2013), and that the data is not captured by the proposed model (Ball \& Shivakumar, 2005);

iv. Continuous variables were standardized by excluding observations above three standard deviations from the standardized mean of each variable. It is worth mentioning that the adoption of this procedure resulted in the exclusion of information from Petróleo Brasileiro SA - Petrobras (a company listed on B3, widely cited in the media for involvement in corruption scandals, mainly in Operation Lava Jato) from the sample, since, on average, its indicators (assets, leverage, and others) differed from the other observations in the sample.

The independent auditors' reports were obtained on the B3 website. Then, we carried out an analysis to identify whether the auditor recorded in his report that the firm was under scrutiny by the press for involvement in corruption in the corresponding year. Thus, 41 reports with such information were identified, being: 11 from Deloitte, 8 from PwC, 6 from KPMG, 5 from Ernst \& Young, and 11 from other non-Big Four independent auditors ( 3 from Grant Thornton, 7 from BDO, and 1 from Baker). These records were made with a disclaimer, emphasis, or key audit matters (KAM), as shown in Table 1.

Table 1

Summary analysis of independent auditors' reports (example)

\begin{tabular}{|c|c|c|c|}
\hline Firm & Independent auditor & Year & Disclaimer / Emphasis / KAM \\
\hline $\begin{array}{l}\text { Andrade Gutierrez } \\
\text { Concessões S. A. }\end{array}$ & $\begin{array}{l}\text { Deloitte Touche } \\
\text { Tohmatsu }\end{array}$ & 2015 & $\begin{array}{l}\text { Disclaimer - Investigations in the indirect investee Norte Energia S. A. ref. possible } \\
\text { non-compliance with laws and regulations. } \\
\text { Emphasis - Audit report of indirect investee Madeireira Energia S. A. - MESA ref. } \\
\text { investigations and legal measures from the Public Prosecution Office. }\end{array}$ \\
\hline $\begin{array}{l}\text { Andrade Gutierrez } \\
\text { Participações S.A. }\end{array}$ & $\begin{array}{l}\text { Deloitte Touche } \\
\text { Tohmatsu }\end{array}$ & 2015 & $\begin{array}{l}\text { Disclaimer - Risks related to compliance with laws and regulations on indirect } \\
\text { investment in Norte Energia S. A. } \\
\text { Emphasis - Uncertainty related to possible impacts on the FS of the investee Madeira } \\
\text { Energia S. A. - MESA, resulting from the outcome of the investigations and other legal } \\
\text { measures from the Federal Prosecution Service against certain indirect shareholders } \\
\text { and certain executives of these indirect shareholders. }\end{array}$ \\
\hline Braskem S.A. & KPMG Auditores & 2015 & Emphasis - Ongoing internal investigation and Class Action in the United States. \\
\hline Braskem S.A. & KPMG Auditores & 2016 & $\begin{array}{l}\text { Emphasis - Lava Jato investigation, payments without proof of consideration (2006- } \\
\text { 2014), and leniency agreement signed with the Federal Prosecution Service. } \\
\text { KAM - Contingencies and disputes (Lava Jato and Class Action in the United States). }\end{array}$ \\
\hline
\end{tabular}

FS = financial statement.

Source: Prepared by the authors. 
We surveyed the Google website and analyzed news reports that cited the involvement of firms in the corruption sample. Thus, 80 news items were selected, as shown in Table 2, considering the following selection criteria: (i) Main sources: newspapers and magazines of broad circulation and news sites, such as O Globo, Valor, Exame, UOL, O Estado de S. Paulo, Veja, and Carta Capital; (ii) Date: 2010 to 2016; (iii) Firms: only those listed in B3 and included in the sample; (iv) Filter: one report in a given year was considered enough to register occurrence in the database; and (v) News content: mentioning of the firm in the news and what type of investigation it was involved in.

Table 2

Source mentioning the firms in the press (exemplification)

\begin{tabular}{llll}
\hline \multicolumn{1}{c}{ Firm } & \multicolumn{2}{c}{ Source } & Year \\
\hline Alpargatas & http://www.valor.com.br/empresas/4708005/investigados-irmaos-batista-se-afastam-da-jbs-eldorado-e-alpargatas & 2016 \\
\hline Alupar & https://exame.abril.com.br/negocios/bb-e-o-maior-credor-de-empresa-investigada-na-lava-jato/ & 2015 \\
\hline Arteris & http://politica.estadao.com.br/noticias/geral,mp-apura-fraude-em-contratos-de-rodovias-em-sp,1170793 & 2014 \\
\hline Bradespar & https://www.bradespar.com.br/Bradespar/staticfiles/pdf/fatos_relevantes/Comunicado\%20ao\%20Mercado.pdf & 2016 \\
\hline Braskem & $\begin{array}{l}\text { http://g1.globo.com/pr/parana/noticia/2015/06/braskem-encaminha-policia-federal-e-mails-de-ex-funcionario- } \\
\text { investigado.html }\end{array}$ & 2015 \\
\hline Braskem & $\begin{array}{l}\text { https://oglobo.globo.com/brasil/envolvida-na-lava-jato-braskem-comunica-ao-mercado-tentativa-de-acordo-com- } \\
\text { eua-brasil-20237819 }\end{array}$ & 2016 \\
\hline BRF & https://oglobo.globo.com/economia/zelotes-jbs-brf-aparecem-em-gravacoes-15848728 & 2015 \\
\hline S
\end{tabular}

Source: Prepared by the authors.

We found that most of the cases mentioned in the independent auditor's reports were also cited by the press and that not all of the cases disclosed in the press were reported in the independent audit reports.

\subsection{Model and Operational Variables}

The research was based on the model developed by Ball and Shivakumar (2005), related to the timely loss recognition as a measure of QAI, which in turn was elaborated based on Basu's model (1997).

The model measures the timeliness of the accounting information contained in the results, in a context of great scrutiny by the press in case of corruption. We considered the specifications of the original model and added an independent variable, $C_{i t}$. This variable is a dummy variable related to the disclosure of the involvement of firms in investigations of corruption crimes, both by the independent auditor and by the press.

Thus, when the independent auditor reports in his opinion or the press disclose that a firm has been or is being investigated for involvement in corruption crimes, the variable $C_{i t}$ assumes a value of 1 (one). Otherwise, it assumes the value 0 (zero).

The Main Model is described in the following Equation 2:

$$
\begin{gathered}
\text { Varni }_{i t}=\alpha_{0}+\alpha_{1} \text { Dvarni }_{i t-1}+\alpha_{2} \text { Varni }_{i t-1}+\alpha_{3}\left(\text { Varni }_{i t-1} * \text { Dvarni }_{i t-1}\right)+\alpha_{4} C_{i t}+ \\
\alpha_{5}\left(C_{i t} * \text { Dvarni }_{i t-1}\right)+\alpha_{6}\left(C_{i t} * \operatorname{Varni}_{i t-1}\right)+\alpha_{7}\left(C_{i t} * \operatorname{Varni}_{i t-1} * \operatorname{Dvarni}_{i t-1}\right)+ \\
\alpha_{8} \text { VarControle }_{i t}+\varepsilon_{i t}
\end{gathered}
$$

Table 3 presents a description of the variables and the expected signs. 
Table 3

Description of model parameters

\begin{tabular}{|c|c|c|}
\hline Variable & Expected result & Operationalization \\
\hline \multicolumn{3}{|l|}{ Varni $_{i t}$} \\
\hline$\alpha_{1}$ Dvarni $_{i t-1}$ & $(*)$ & $\begin{array}{l}\text { Binary variable that assumes a value of } 1 \text { (one) in case of negative variations in the } \\
\text { previous year's profit and } 0 \text { (zero) in case of positive variations. }\end{array}$ \\
\hline$\alpha_{2}$ Varni $_{i t-1}$ & $\alpha_{2}=0$ & $\begin{array}{l}\text { Variable that represents the variation in net profit of firm } i \text { in year } t-1 \text {, weighted by the total } \\
\text { assets at the beginning of year } t-1 \text {. Indicates the persistence of profit. }\end{array}$ \\
\hline$\alpha_{3}\left(\right.$ Varni $_{i t-1} *$ Dvarni $\left._{i t-1}\right)$ & $\alpha_{3}<0$ & Interaction variable of negative profit variations. Differentiates the type of profit variations. \\
\hline$\alpha_{4} C_{i t}$ & $\alpha_{4}<0$ & $\begin{array}{l}\text { Binary variable that indicates the existence of disclosure of the involvement of firms in } \\
\text { investigations of corruption crimes. Assumes a value of } 1 \text { (one) when there the firm is } \\
\text { mentioned, and } 0 \text { (zero) when it is not mentioned. }\end{array}$ \\
\hline$\alpha_{5}\left(C_{i t} * D v a r n i_{i t-1}\right)$ & $(*)$ & $\begin{array}{c}\text { Interaction variable between the negative variations in the profit of firms cited in } \\
\text { investigations of corruption crimes. }\end{array}$ \\
\hline$\alpha_{6}\left(C_{i t} * \operatorname{Varni}_{i t-1}\right)$ & $\alpha_{6}=0$ & $\begin{array}{l}\text { Variable of interaction between variations in the net profit of firms cited in investigations of } \\
\text { corruption crimes. Differentiates the mentioned firms. }\end{array}$ \\
\hline$\alpha_{7}\left(C_{i t} * \operatorname{Varni}_{i t-1} * \operatorname{Dvarni}_{i t-1}\right)$ & $\alpha_{7}<0$ & $\begin{array}{l}\text { Interaction variable for negative variations in the net profit of firms cited in investigations } \\
\text { of corruption crimes. Differentiates the firms mentioned }\end{array}$ \\
\hline$\alpha_{8} \operatorname{VarControle}_{i t}$ & $(*)$ & $\begin{array}{l}\text { Control variables, namely: (a) logarithm of the firm's total assets (Ln Ativo }) \text {; (b) return } \\
\text { on assets }\left(\mathrm{ROA}_{\mathrm{it}}\right) ; \text { (c) Dummy variable that indicates whether the firm's net profit was } \\
\left.\text { negative (Dperda } \mathrm{it}_{\mathrm{it}}\right) \text {, assuming the value } 1 \text { (one) if net profit is less than } 0 \text { (zero) or } 0 \text { (zero) } \\
\left.\text { otherwise; (d) firm leverage (Alafin }{ }_{\mathrm{it}}\right) ; \text { and (e) operating cash flow weighted by total assets } \\
\text { at the beginning of the year }\left(\mathrm{FCO}_{\mathrm{it}}\right) \text {. }\end{array}$ \\
\hline
\end{tabular}

(*) Ball e Shivakumar (2005) do not offer interpretation for the sign of the coefficients $\alpha_{0}$ e $\alpha_{1}$.

Source: Prepared from Paulo et al. (2013); Ball and Shivakumar (2005); Coelho, Cia and Lima (2009); Lennox, Francis and Wang (2012); and Chaney, Jeter and Shivakumar (2004), Basu (1997).

The coefficients of interest are those that contain the interaction with the characteristic "corruption", $C_{i t}$, that is, $\alpha_{5}, \alpha_{6}$ and $\alpha_{7}$, and all are expected to be significant and negative.

To obtain the complete effect of the negative variations in the profits of the sample firms, we analyzed the sum of the coefficients $\alpha_{2}+\alpha_{3}$, which is estimated to be less than zero, indicating the occurrence of reversal of the transient components in the profits. And, to obtain the complete effect of the negative variations in the profits of the firms mentioned in investigations of corruption crimes, we analyzed the sum of the coefficients $\alpha_{2}+\alpha_{3}+\alpha_{6}+\alpha_{7}$, which must be greater than $\alpha_{2}+\alpha_{3}$, indicating the occurrence of reversal of transitory components in profits.

Table 4 describes the control variables of the models. LnAtivo controls the size of the firm; ROA and Dperda control the effects of profitability; and FCO and Alafin control debt and cash flow.

Table 4

Summary of control variables used in the model

\begin{tabular}{cc}
\hline Variable & Formula \\
\hline LnAtivo $=$ Logarithm of total firm assets (Size) & Ln (Total Assets) \\
\hline ROA $=$ Return on firm assets (Profitability) & Net profit/((Total Assets $(t)+$ Total Assets $(t+1)) / 2)$ \\
\hline Dperda $=$ Dummy variable that assesses the profit behavior & Assumes value $(1)$ if net profit $<0$ and value $(0)$ if net profit $>=0$ \\
\hline FCO = Firm's operating cash flow weighted by total assets & Cash flow / Total Assets at the beginning of the year \\
\hline Alafin = Degree of financial leverage (Indebtedness) & (Net Profit/PL / (Net Profit / Total Assets) \\
\hline
\end{tabular}

Source: Prepared from Paulo et al. (2013); Lennox et al. (2012); and Chaney et al. (2004).

The regressions were estimated using the Stata 13 software, through the pooled approach using the Ordinary Least Squares (OLS) estimation method, clustered by year and economic sector, as proposed by Ball and Shivakumar
(2005). Additionally, simulations were carried out in clustered OLS per year and economic sector with the Heteroskedasticity-Robust Inference and Generalized Least Squares (GLS) estimators. 
Analysis of the assumptions of linear regression was carried out by applying the following tests: (i) ShapiroFrancia test to assess the hypothesis of a normal distribution of residues; (ii) White test to verify the hypothesis of homoscedasticity (if the variance of the residuals is constant); and (iii) Durbin-Watson test to assess the hypothesis of non-autocorrelation of the residues, that is, if the residues are independent. In addition to the assumptions, the Variance Inflation Factor (VIF) was estimated to identify the occurrence of multicollinearity between the explanatory variables, and the obtained VIFs were below 4.
The White and Durbin-Watson tests identified, respectively, the heteroscedasticity and autocorrelation of the error terms. To address this issue, we carried out simulations with the following estimators described by Wooldridge (2012): (i) Heteroskedasticity-Robust Inference, to adjust standard errors and statistics, so that they are valid in the presence of heteroscedasticity with an unknown form; and (ii) the Generalized Least Squares (GLS), which allows the correlation of the residuals. The analysis with the GLS estimator is presented in the main results, and the results of three other analysis are present in Appendix A.

\section{ANALYSIS OF RESULTS}

To analyze the effect of disclosing the involvement of firms in corruption cases in increasing the timely loss recognition, we estimated the parameters of Equation 2 in the Main Model. Additionally, considering that the literature describes that economic crises can affect the level of accounting conservatism, to assess the impacts of the 2014-2016 economic crisis we estimated the parameters in the same Equation 2 in the Crisis Model. This model considers an additional binary variable, which assumes value 1 (one) for years of crisis and value 0 (zero) for years in which there was no crisis.

\subsection{Descriptive Statistics}

Table 5 presents the descriptive statistics of the main variables of the model adopted in this study.

Table 5

Descriptive statistics

\begin{tabular}{|c|c|c|c|c|c|c|c|c|}
\hline Variable & Obs. & Mean & Median & SD & Minimum & Maximum & $\begin{array}{c}\text { 25th } \\
\text { percentile }\end{array}$ & $\begin{array}{c}\text { 75th } \\
\text { percentile }\end{array}$ \\
\hline $\operatorname{Varni}_{i t}$ & 1824 & -0.0075 & -0.0008 & 0.3653 & -11.7466 & 5.7091 & -0.0266 & 0.0184 \\
\hline $\operatorname{Dvarni}_{\mathrm{it}}\left(\alpha_{1}\right)$ & 1824 & 0.4879 & 0.0000 & 0.4999 & 0.0000 & 1.0000 & 0.0000 & 1.0000 \\
\hline $\operatorname{Varni}_{\mathrm{it}-1}\left(a_{2}\right)$ & 1824 & -0.0013 & 0.0006 & 0.5783 & -11.7466 & 16.9139 & -0.0229 & 0.0207 \\
\hline Dvarni $_{\mathrm{it}-1} * \operatorname{Varni}_{\mathrm{it}-1}\left(\alpha_{3}\right)$ & 1824 & -0.04173 & 0.0000 & 0.3184 & -11.7466 & 0.0000 & -0.0229 & 0.0000 \\
\hline $\mathrm{C}_{\mathrm{it}}\left(\mathrm{a}_{4}\right)$ & 1824 & 0.1798 & 0.0000 & 0.3841 & 0.0000 & 1.0000 & 0.0000 & 0.0000 \\
\hline Cit $*$ Dvarni $_{\mathrm{it}-1}\left(\alpha_{5}\right)$ & 1824 & 0.0997 & 0.0000 & 0.2997 & 0.0000 & 1.0000 & 0.0000 & 0.0000 \\
\hline Cit $* \operatorname{Varni}_{\mathrm{it}-1}\left(\alpha_{6}\right)$ & 1824 & 0.0026 & 0.0000 & 0.2840 & -4.4524 & 11.0000 & 0.0000 & 0.0000 \\
\hline Cit $^{*}$ Dvarni $_{\mathrm{it}-1} * \operatorname{Varni}_{\mathrm{it}-1}\left(\alpha_{7}\right)$ & 1824 & -0.0076 & 0.0000 & 0.1114 & -4.4524 & 0.0000 & 0.0000 & 0.0000 \\
\hline LnAtivo $_{i t}$ & 1824 & 14.5075 & 14.7017 & 1.8277 & 8.9084 & 19.6606 & 13.3867 & 15.7328 \\
\hline Dperda $_{i t}$ & 1824 & 0.3267 & 0.0000 & 0.4691 & 0.0000 & 1.0000 & 0.0000 & 1.0000 \\
\hline$R O A_{i t}$ & 1824 & 0.0096 & 0.0241 & 0.1362 & -1.0149 & 1.0437 & -0.0189 & 0.0685 \\
\hline Alafin $_{i t}$ & 1824 & 2.1581 & 1.500 & 42.148 & -754.80 & 741.1 & 0.5000 & 2.4000 \\
\hline$F C O_{i t}$ & 1824 & 0.0609 & 0.0587 & 0.1071 & -1.8679 & 1.0662 & 0.0152 & 0.1101 \\
\hline
\end{tabular}

Notes: (i) Varni $_{i t}=$ variation in net profit of firm i from year $t$ - 1 to year $t$, weighted by total assets at the beginning of year $t$; Varni $_{i t-1}=$ variation in net profit of firm $i$ from year $t-2$ to year $t-1$, weighted by total assets at the beginning of year $t-1$; Dvarni ${ }_{i t-1}$ $=$ dummy variable that indicates whether there is a negative variation in the net profit of firm $i$ from year $t-1$ to year $t$, assuming a value of 1 (one) if Varni ${ }_{i t}<0$, or 0 (zero) otherwise; $L n$ Ativo ${ }_{i t}=$ logarithm of total assets of firm $i$ in year $t$; $R O A_{i t}=$ return on assets of firm $i$ in year $t$; Dperda ${ }_{i t}=$ dummy variable that indicates whether the net profit of firm $i$ in year $t$ was negative, assuming a value of 1 (one) if Lucro $_{i t}<0$, or 0 (zero) otherwise; Alafin ${ }_{i t}=$ leverage of firm $i$ in year $t$; FCO $_{i t}=$ operating cash flow of firm $i$

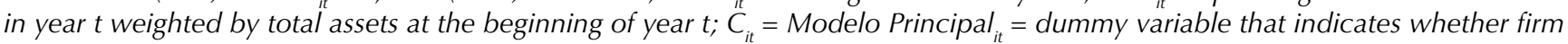
$i$ was mentioned in a corruption crime investigation in year $t$, in which it assumes a value of 1 (one), or 0 (zero) otherwise; (ii) Obs = observations; $S D=$ standard deviation.

Source: Prepared by the authors. 
Note that due to the effect of the economic crisis that lasted for successive years (2014 to 2016), the variable Varni $_{i t-1}$ has a mean and median lower than the same statistics as the variable Varni $i_{i t}$, which signals a reduction in corporate profits in the current period at the expense of profit in the previous period. This highlights the relevance of controlling for the economic crisis factor when analyzing this work's conclusions.

The Financial Leverage indicator (Alafin) mean was 2.1581 , a value above the median. The same occurs with the Operating Cash Flow (FCO) indicator, which presented a mean of 0.0609 , also above the median. This indicates that the results of this work are being influenced by firms with greater leverage and which have more representative cash flows since they make up the 75th percentile of the distribution.

\subsection{Correlation Matrix}

Table 6 presents the estimated correction between the variables of the model adopted in this study.

Table 6

Pearson Correlation Matrix

\begin{tabular}{|c|c|c|c|c|c|c|c|c|}
\hline Variable & Varni $_{i t}$ & Dvarni $_{i t-1}$ & Varni $_{i t-1}$ & Ln Ativo $_{\text {it }}$ & Dperda $_{\text {it }}$ & $\mathrm{ROA}_{i t}$ & Alafin $_{\text {it }}$ & $\mathrm{FCO}_{\mathrm{it}}$ \\
\hline Varni $_{\text {it }}$ & 1 & & & & & & & \\
\hline Dvarni $_{\mathrm{it}-1}$ & 0.0853* & 1 & & & & & & \\
\hline $\operatorname{Varni}_{\mathrm{it}-1}$ & $-0.7178^{*}$ & $0.1422 *$ & 1 & & & & & \\
\hline Ln Ativo $_{i t}$ & 0.0344 & -0.0107 & 0.0000 & 1 & & & & \\
\hline Dperda $_{\text {it }}$ & $-0.1153^{*}$ & 0.1945* & 0.0070 & $-0.1561 *$ & 1 & & & \\
\hline $\mathrm{ROA}_{\mathrm{it}}$ & 0.3138* & $-0.1757^{*}$ & $-0.1162^{*}$ & 0.1716* & $-0.6172 *$ & 1 & & \\
\hline Alafin $_{\text {it }}$ & 0.0115 & -0.0433 & -0.0194 & 0.0044 & -0.0258 & 0.0304 & 1 & \\
\hline $\mathrm{FCO}_{\text {it }}$ & -0.0422 & $-0.0863^{*}$ & 0.0122 & $0.0974 *$ & $-0.3008^{*}$ & 0.03611* & 0.0136 & 1 \\
\hline
\end{tabular}

Notes: (i) Varni ${ }_{i t}=$ variation in net profit of firm i from year $t-1$ to year $t$, weighted by total assets at the beginning of year $t$; Varni $_{i t-1}=$ variation in net profit of firm $i$ from year $t-2$ to year $t-1$, weighted by total assets at the beginning of year $t-1$; Dvarni ${ }_{i t-1}$ $=$ dummy variable that indicates whether there is a negative variation in the net profit of firm $i$ from year $t-1$ to year $t$, assuming a value of 1 (one) if Varni $i_{i t}<0$, or 0 (zero) otherwise; $L n$ Ativo ${ }_{i t}=$ logarithm of total assets of firm $i$ in year $t$; $R O A_{i t}=$ return on assets of firm $i$ in year $t$; Dperda $a_{i t}=$ dummy variable that indicates whether the net profit of firm $i$ in year $t$ was negative, assuming a value of 1 (one) if Lucro $_{i t}<0$, or 0 (zero) otherwise; Alafin ${ }_{i t}=$ leverage of firm $i$ in year $t$; COO $_{i t}=$ operating cash flow of firm i in year $t$ weighted by total assets at the beginning of year $t$.

* indicates a significance level of $5 \%$, marked in bold.

Source: Prepared by the authors.

In Table 6, the dependent variable Varni ${ }_{i t}$ (variation in net income in the current period) showed a significant and negative correlation with the following variables: (i) Varni $_{i t-1}$ (variation in lagged net income); and (ii) FCO (operating cash flow of the firm), in line with Ball and Shivakumar (2005), which signals a trend of timely loss recognition.

\subsection{Regression Models}

Table 7 presents the results of the regressions of the Main Model and the Crisis Model, estimated using the pooled approach through the OLS estimation method, clustered by year and economic sector, and the Generalized Least Squares (GLS) estimator. 
Table 7

Regression model estimates

\begin{tabular}{|c|c|c|c|c|}
\hline \multirow{2}{*}{ Varni $_{i t}$} & \multicolumn{2}{|c|}{ Main Model } & \multicolumn{2}{|c|}{ Crisis Model } \\
\hline & Coef. & p-value & Coef. & p-value \\
\hline Constante $\left(\alpha_{0}\right)$ & 0.0401283 & 0.004 & 0.0534578 & 0.008 \\
\hline $\operatorname{Dvarni}_{i t-1}\left(\alpha_{1}\right)$ & 0.0067331 & 0.002 & 0.0070135 & 0.001 \\
\hline $\operatorname{Varn}_{i t-1}\left(\alpha_{2}\right)$ & -0.5946120 & 0.000 & -0.5325127 & 0.000 \\
\hline $\operatorname{Dvarni}_{i t-1} * \operatorname{Varni}_{i t-1}\left(\alpha_{3}\right)$ & 0.4216917 & 0.000 & 0.1861643 & 0.000 \\
\hline$C_{i t}(\alpha 4)$ & -0.0095063 & 0.019 & -0.0098676 & 0.021 \\
\hline$C_{i t}^{*} \operatorname{Dvarni}_{i t-1}\left(\alpha_{5}\right)$ & 0.0145291 & 0.000 & 0.0057386 & 0.220 \\
\hline$C_{i t}^{*} \operatorname{Varni}_{i t-1}\left(\alpha_{6}\right)$ & 0.2183516 & 0.000 & 0.2341382 & 0.000 \\
\hline$C_{i t}^{*}{ }^{*} \operatorname{varni}_{i t-1}{ }^{*} \operatorname{Varni}_{i t-1}\left(\alpha_{7}\right)$ & -0.1396247 & 0.003 & -0.4587068 & 0.000 \\
\hline Ln Ativo $_{i t}$ & -0.0042459 & 0.000 & -0.0059938 & 0.000 \\
\hline Dperda $_{i t}$ & 0.0101151 & 0.000 & 0.0000755 & 0.980 \\
\hline$R O A_{i t}$ & 0.883639 & 0.000 & 0.8620915 & 0.000 \\
\hline Alafin $_{i t}$ & -0.0005893 & 0.012 & -0.0000224 & 0.321 \\
\hline $\mathrm{FCO}_{i t}$ & -0.2972948 & 0.000 & -0.1554819 & 0.000 \\
\hline AnoCrise $_{i t}$ & - & - & 0.0241777 & 0.000 \\
\hline
\end{tabular}

Notes: (i) Varni ${ }_{i t}=$ variation in net profit of firm i from year $t-1$ to year $t$, weighted by total assets at the beginning of year $t$; Varni $_{i t-1}=$ variation in net profit of firm $i$ from year $t-2$ to year $t-1$, weighted by total assets at the beginning of year $t-1 ;$ Dvarni ${ }_{i t-1}$ $=$ dummy variable that indicates whether there is a negative variation in the net profit of firm $i$ from year $t-1$ to year $t$, assuming a value of 1 (one) if Varni ${ }_{i t}<0$, or 0 (zero) otherwise; $L_{n}$ Ativo ${ }_{i t}=$ logarithm of total assets of firm $i$ in year $t$; $R O A_{i t}=$ return on assets of firm $i$ in year $t$; Dperda ${ }_{i t}=d u m m y$ variable that indicates whether the net profit of firm $i$ in year $t$ was negative, assuming a value of 1 (one) if Lucro $_{i t}<0$, or 0 (zero) otherwise; Alafin ${ }_{i t}=$ leverage of firm $i$ in year $t$; FCO $i t=$ operating cash flow of firm $i$ in year $t$ weighted by total assets at the beginning of year $t ; C_{i t}=$ Modelo Principal ${ }_{i t}=$ dummy variable that indicates whether firm $i$ was mentioned in a corruption crime investigation in year $t$, in which it assumes a value of 1 (one), or 0 (zero) otherwise; $C_{i t}=$ Crisis Modelo $_{i t}=$ dummy variable indicating whether year $t$ is a year of crisis, in which it assumes a value of 1 (one), or 0 (zero) otherwise.

Source: Prepared by the authors.

The interpretation of the recognition of gains and losses, following Ball and Shivakumar (2005) follows: gains in firms that were not mentioned: $\alpha_{2}$; losses in firms that were not mentioned: $\alpha_{2}+\alpha_{3}$; gains in the firms mentioned in cases of corruption: $\alpha_{2}+\alpha_{6}$; losses in firms mentioned in cases of corruption: $\alpha_{2}+\alpha_{3}+\alpha_{6}+\alpha_{7}$.

To assess the full effect of timely loss recognition, we add the coefficients $\alpha_{2}+\alpha_{3}$, resulting in a value less than zero in both the Main Model (-0.1729203) and the Crisis Model (-0.3463484). This result corroborates the idea of conditional recognition behavior. However, it is important to observe the intensity of this value in a crisis period, which indicates an increase in conditional behavior in this period.

Note that $\alpha_{7}$ is less than zero, which shows that losses tend to be recognized in a timely manner when these firms are exposed by the media and auditors in situations that involve corruption. This occurs in both the Main and Crisis Models, indicating that the disclosure made by the media and auditors interferes with the timely loss recognition. However, when the analysis is expanded and the sum of the coefficients is $\alpha_{2}+\alpha_{3}+\alpha_{6}+\alpha_{7}$ is considered, although the result continues to corroborate the existence of conditional recognition, its intensity is lower, in the opposite direction of the hypothesis suggested in this paper. In the Main Model, the sum of the four coefficients is $(-0.0941934)$, being greater than the sum of the coefficients $\alpha_{2}+\alpha_{3}(-0.1729203)$. Note that this differs in the model in which the effect of the Crisis is evaluated, in which $\alpha_{2}+\alpha_{3}$ is equal to -0.3463484 and the sum $\alpha_{2}+\alpha_{3}+\alpha_{6}+\alpha_{7}$ is -0.5709170 . In other words, the effect of the crisis seems to have a greater impact on timely loss recognition than the disclosure of the firm's involvement in corruption schemes.

An explanation for the lower impact of the media is provided by Pinho and Sacramento (2009), who analyzed the concept of vertical accountability. The authors explain that the "vertical" characteristic concerns the dimension of forces external to the connections involved in the possible act of corruption, citing as an example the social demands and the media performance. The authors argue that the relevance of media performance can decrease when it is 
seen as partial, that occurs when it defines or names those alleged to be responsible for the crimes of corruption, and, at other times, contributes to the conviction of innocents by public opinion instead of the real culprits. As shown, the subject has complex dimensions.

Regarding the accounting aspect, we highlight some elements that can change the behavior of timely loss recognition. One of these factors refers to earnings management, as discussed by Moreira (2009). Firms manage their results through the choice of accounting criteria to meet different interests. If those interests come from political connections, for example, and if those connections are very strong, the timely loss recognition aspect can be attenuated. And, to a certain extent, this could justify the lack of response to the pressure of media scrutiny in recognizing the loss, as the strong political connection can reduce the fear of punishment of fraud by the firms that have these connections (Lazzarini, 2011).

\section{FINAL CONSIDERATIONS}

This study investigated the relationship between the disclosure of the involvement of firms in corruption investigations and the timely loss recognition, with the latter as a proxy for the quality of accounting information.

Thus, we based our study on previous researches that evaluated the interaction between media scrutiny and the disclosure of deficiencies in internal controls by independent auditor's reports; Based on this literature, we included the perspective of vertical accountability (external/media) and the perspective of the insider (auditor) as reducers of information asymmetry.

Following the model developed by Ball and Shivakumar (2005), we included specific characteristics to test the hypothesis that the disclosure of the involvement of Brazilian firms in investigations of corruption crimes increases the timely loss recognition. The results show that timely loss recognition allows us to characterize accounting conservatism in the firms cited in corruption schemes. However, when compared to the group of firms that were not mentioned in the media, this conditional behavior is shown to be lower, rather than greater, as suggested by our research hypothesis, which may indicate that the citation in corruption schemes alone does not increase the timely loss recognition. The expected behavior with the analysis of corruption news was equal to the behavior observed when the conditional behavior calculation was controlled by periods of economic crisis, in which periods of crisis enhance timely loss recognition.

The smaller impact of media scrutiny may be related to other factors not addressed in this research, such as the immaturity of our popular action institutions, or even the cultural filter by which the information is subject, decreasing its impact in the Brazilian context (Sacramento \& Pinho, 2016).

A better understanding of the impact caused by information from the specialized media in a society that can be influenced by social networks, public opinion drivers, and disinformation emitters is also necessary (Cardoso, 2019). In terms of the operational aspect of the research, another limitation is the wide dispersion and variety of news published on the internet on the topic of corruption and the involvement of Brazilian firms in the practice. This can hinder data collection and decrease the possible impact of the news and, depending on how society sees such a vehicle (positioning bias), the news may lose its informative value (Sacramento \& Pinho, 2016).

It is also very important to point out that the complexity of the theme requires an important modeling effort, which may not be fully described without considering elements outside the accounting context that are specific to Brazil and may be important in interpreting a broader context of fraud (Lazzarini, 2011). It is necessary to model how the other levers that induce fraud and opportunistic accounting choices that were not addressed by this research, based, for instance, on political connections, off-balance transactions, corporate governance, aggressiveness in the interpretation and application of accounting standards, compliance, and audit mechanisms (Murcia, 2007).

We also highlight the role of corporate governance as a suggestion for future research on this topic, which should ensure the mapping of the potential risks of maneuvering existing internal controls and prevent other interests from interfering in the preparation of the financial statements. On the other hand, the Audit should also be able to guarantee accounting statements in line with current norms and without frauds.

The corruption issue remains relevant for society and, especially, for accounting professionals, who can play an important role in avoiding the occurrence of new cases of corruption and the harmful effects of such practice, clarifying the impact that corruption imposes on financial statements and fostering the interest of civil society in acting and pushing for improvements in public governance. 


\section{REFERENCES}

Amaral, M. A., \& Santos, O. M. (2017). Efeito no preço das ações de empresas punidas por corrupção no âmbito do FCPA. Revista Universo Contábil, 13(2), 109-129.

Antunes, G. A., \& Mendonça, M. D. (2008). Impacto da adesão aos níveis de governança da BOVESPA na qualidade da informação contábil: uma investigação acerca da oportunidade, relevância e do conservadorismo contábil utilizando dados em painel. Anais do Congresso da Associação Nacional dos Programas de Pós-graduação em Ciências Contábeis.

Ball, R., \& Shivakumar, L. (2005). Earnings quality in UK private firms: comparative loss recognition timeliness. Journal of Accounting and Economics, 39(1), 83-128.

Basu, S. (1997). The conservatism principle and the asymmetric timeliness of earnings. Journal of Accounting and Economics, 24(1), 3-37.

Beams, J., \& Yan, Y. C. (2015). The effect of financial crisis on auditor conservatism: US evidence. Accounting Research Journal, 28(2), 160-171.

Bhattacharya, U., Daouk, H., \& Welker, M. (2003). The world price of earnings opacity. The Accounting Review, 78(3), 641678.

Caldas, O. V., Costa, C. M., \& Pagliarussi, M. S. (2016). Corrupção e composição dos gastos governamentais: evidências a partir do Programa de Fiscalização por Sorteios Públicos da Controladoria-Geral da União. Revista de Administração Pública, 50(2), 237-264.

Cardoso, I. A. (2019). Propagação e influência de pós-verdade e fake news na opinião pública. (Dissertação de Mestrado). Universidade de São Paulo, São Paulo.

Chaney, P. K., Faccio, M. \& Parsley, D. (2010). The quality of accounting information in politically connected firms. Journal of Accounting and Economics, 51(1-2), 58-76.

Chaney, P. K., Jeter, D. C., \& Shivakumar, L. (2004). Self-selection of auditors and audit pricing in private firms. The Accounting Review, 74(1), 51-72.

Chen, H., Tang, Q. T., Jiang, Y., \& Lin, Z. (2010). The role of international financial reporting standards in accounting quality: Evidence from the European Union. Journal of International Financial Management \& Accounting, 21(3), 220-278.

Chen, Y., Che, L., Zheng, D., \& You, H. (2020). Corruption culture and accounting quality. Journal of Accounting and Public Policy, 39(2), 106698.

Coelho, A. C. D., Cia, J. N. S., \& Lima, I. S. (2009)

Conservadorismo condicional na divulgação de lucros em companhias abertas brasileiras: diferenças entre emissoras e não emissoras de ADR'S e sistemas contábeis. Revista de Administração Mackenzie, 11(1), 117-149.

Defond, M., \& Zhang, J. (2014). A review of archival auditing research. Journal of Accounting and Economics, 58(2-3), 275326.
Delavallade, C. (2006). Corruption and distribution of public spending in developing countries. Journal of Economics and Finance, 30(2), 222-239.

Dhaliwal, D. S., Liu, Q., Xie, H., \& Zhang, J. (2017). Negative press coverage, litigation risk, and audit opinions in China. SSRN Eletronic Journal.

Dowbor, L. (2012). Os caminhos da corrupção: uma visão sistêmica. Economia Global e Gestão, 17(3), 77-105.

Feldmann, D. A., \& Read, W. J. (2010). Auditor conservatism after Enron. Auditing: A Journal of Practice \& Theory, 29(1), 267-278.

Feltham, G. A., \& Ohlson, J. A. (1995). Valuation and clean surplus accounting for operating and financial activities. Contemporary Accounting Research, 11(2), 689-731.

Ferraz, C., \& Finan, F. (2008). Exposing corrupt politicians: the effects of Brazil's publicly released audits on electoral outcomes. The Quarterly Journal of Economics, 123(2), 703-745.

Ferraz, C., Finan, F., \& Moreira, D. B. (2012). Corrupting learning: Evidence from missing federal education funds in Brazil. Journal of Public Economics, 96(9-10), 712-726.

Garcia, L. M., \& Teodósio, A. S. S. (2020). Análise de limites dos sistemas de contabilidade e controle para o enfretamento do problema da corrupção sistêmica no Brasil: lições dos casos da Suécia e da Itália. Revista de Administração Pública, 54(1), 79-98.

Jensen, M. C., \& Meckling, W. H. (1976). Theory of the firm: Managerial behavior, agency costs and ownership structure. Journal of Financial Economics, 3(4), 305-360.

Kaufmann, D. (2015). Corruption matters. Finance \& Development, 52(3), 20-23.

Lara, J. M. G., Osma, B. G., \& Penalva, F. (2009). Accounting conservatism and corporate governance. Review of Accounting Studies, 14(1), 161-201.

La Porta, R., Lopez-de-Silanes, F., Shleifer, A., \& Vishny, R. (2000). Investor protection and corporate governance. Journal of Financial Economics, 58(1), 3-27.

Lazzarini, S. G. (2011). Capitalismo de laços: os donos do Brasile suas conexões. Rio de Janeiro, RJ: Elsevier.

Lennox, C., Francis, J. R., \& Wang, Z. (2012). Selection models in accounting research. The Accounting Review, 87(2), 589-616.

Malagueño, R., Albrecht, C. O., Ainge, C. S., \& Stephens, N. (2010). Accounting and corruption: A cross-country analysis. Journal of Money Laundering Control, 13(4), 372-393.

Mauro, P. (1996). The effects of corruption on growth, investment, and government expenditure. International Monetary Funds Working Paper. Recuperado de https://www.imf. org/en/Publications/WP/Issues/2016/12/30/The-Effectsof-Corruptionon-Growth-Investment-and-GovernmentExpenditure-2042.

Moreira, R. L. (2009). Conservadorismo contábil e abordagem da informação: estudo inferencial em empresas de capital aberto. 
(Dissertação de Mestrado). Universidade Federal de Minas Gerais, Belo Horizonte.

Murcia, F. (2007). Relevância dos red flags na detecção do risco de fraudes nas demonstrações contábeis: a percepção de auditores independentes brasileiros. (Dissertação de mestrado). Universidade Federal de Santa Catarina, Florianópolis.

Nguedie, Y. H. N. (2018). Corruption, investment and economic growth in developing countries: A Panel Smooth Transition Regression Approach. SocioEconomic Challenges, 2(1), 6368.

Paulo, I. I. S. L. M., Cavalcante, P. R. N., \& Paulo, E. (2013). Relação entre qualidade da auditoria e conservadorismo contábil nas empresas brasileiras. Revista de Educação e Pesquisa em Contabilidade, 7(3), 305-307.

Pinheiro, B. G., De Luca, M. M. M., \& Vasconcelos, A. C. D. (2016). Conexões políticas nas maiores companhias listadas na BM\&FBovespa. Revista Eletrônica de Administração, 22(2), 394-418.

Pinho, J. A. G. D., \& Sacramento, A. R. S. (2009). Accountability: já podemos traduzi-la para o português? Revista de Administração Pública, 43(6), 1343-1368.

Pletsch, A. L. B., Moura, G. D., \& Salla, N. M. G. (2018). Influência das conexões políticas no custo de financiamento da dívida das companhias abertas listadas na B3. In Vigésimo quinto Congresso Brasileiro de Custos. Vitória, ES.

Rady, T. (2016). Corruption, business, and economic development. Journal of Organizational Culture, Communications and Conflict, 20(1), 45-55.

Riahi-Belkaoui, A. (2004). Effects of corruption on earnings opacity internationally. Advances in International Accounting, 17, 73-84.
Sacramento, A. R. S., \& de Pinho, J. A. G. (2016). O processo de implementação da answerability no Brasil contemporâneo. Revista de Administração Pública, 50(2), 193-213.

Sacramento, A. R. S., \& Pinho, J. A. G. (2018). Combate à corrupção no Brasil: Identificando entraves à luz da versão revisitada da teoria da modernização. Revista Interdisciplinar de Gestão Social, 7(1), 113-134.

Sargiacomo, M., Ianni, L., D’Andreamatteo, A., \& Servalli, S. (2015). Accounting and the fight against corruption in Italian government procurement: A longitudinal critical analysis (1992-2014). Critical Perspectives on Accounting, 28, 89-96.

Santos, L. C., \& Takamatsu, R. T. (2018). Nível de corrupção dos países e opacidade dos resultados contábeis. Enfoque: Reflexão Contábil, 37(4), 21-32.

Shleifer, A., \& Vishny, R. W. (1993). Corruption. The Quarterly Journal of Economics, 108(3), 599-617.

Sodré, A. C. D. A., \& Alves, M. F. C. (2010). Relação entre emendas parlamentares e corrupção municipal no Brasil: estudo dos relatórios do programa de fiscalização da Controladoria-Geral da União. Revista de Administração Contemporânea, 14(3), 414-433.

Suzart, J. A. (2012). Burocracia, corrupção e ambiente econômico: um panorama sobre o nível mundial de evidenciação empresarial. In Sexto Congresso ANPCONT. Florianópolis, SC.

Watts, R. L. (2003). Conservatism in accounting part I: Explanations and implications. Accounting Horizons, 17(3), 207-221.

Wooldridge, J. M. (2012). Introductory Econometrics: a Modern Approach. Mason, $\mathrm{OH}$ : South-Western Cengage Learning.

Yoon, S. (2007). Accounting quality and international accounting convergence. ( $\mathrm{PhD}$ Thesis). Oklahoma State University, Oklahoma. 


\section{APPENDIX A}

Results from Pooled OLS Regression Model vs. Polled OLS with Heteroskedasticity-Robust Inference Estimator vs. Polled OLS with Generalized Least Squares (GLS) Estimator

\begin{tabular}{|c|c|c|c|}
\hline \multirow{2}{*}{ Varni $_{i t}$} & \multicolumn{3}{|c|}{ MAIN MODEL } \\
\hline & ( 1 ) & ( 2 ) & ( 3 ) \\
\hline \multirow{2}{*}{ Constante $\left(\alpha_{0}\right)$} & $0.107^{* * *}$ & $0.107^{* *}$ & $0.0401^{* * *}$ \\
\hline & $(2.85)$ & $(2.28)$ & $(2.92)$ \\
\hline \multirow{2}{*}{$\operatorname{Dvarni}_{i t-1}\left(\alpha_{1}\right)$} & 0.0143 & $0.0143^{*}$ & $0.00673^{* * *}$ \\
\hline & $(1.57)$ & $(1.88)$ & $(3.11)$ \\
\hline \multirow{2}{*}{$\operatorname{Varn}_{i t-1}\left(\alpha_{2}\right)$} & $-0.650^{* * *}$ & $-0.650^{* * *}$ & $-0.595^{* * *}$ \\
\hline & $(-76.99)$ & $(-50.04)$ & $(-27.22)$ \\
\hline \multirow{2}{*}{$\operatorname{Dvarni}_{i t-1} * \operatorname{Varni}_{i t-1}\left(\alpha_{3}\right)$} & $0.542^{* * *}$ & $0.542^{* * *}$ & $0.422^{* * *}$ \\
\hline & $(37.73)$ & (13.45) & (12.54) \\
\hline \multirow{2}{*}{$C_{i t}\left(\alpha_{4}\right)$} & -0.0216 & -0.0216 & $-0.00951^{* *}$ \\
\hline & $(-1.25)$ & $(-1.62)$ & $(-2.35)$ \\
\hline \multirow{2}{*}{$C_{i t}^{*} \operatorname{Dvarni}_{i t-1}\left(\alpha_{5}\right)$} & 0.0217 & 0.0217 & $0.0145^{* * *}$ \\
\hline & $(1.07)$ & $(1.20)$ & $(3.50)$ \\
\hline \multirow{2}{*}{$C_{i t}^{*} \operatorname{Varni}_{i t-1}\left(\alpha_{6}\right)$} & $0.257^{* * *}$ & $0.257^{* * *}$ & $0.218^{* * *}$ \\
\hline & (16.89) & (21.46) & $(8.88)$ \\
\hline \multirow{2}{*}{$C_{i t}^{*} \operatorname{Dvarni}_{i t-1}{ }^{*} \operatorname{Varni}_{i t-1}\left(\alpha_{7}\right)$} & $-0.228^{* * *}$ & $-0.228^{* * *}$ & $-0.140^{* * *}$ \\
\hline & $(-6.19)$ & $(-3.06)$ & $(-3.01)$ \\
\hline \multirow{2}{*}{ Ln Ativo $_{i t}$} & $-0.00843^{* * *}$ & $-0.00843^{* * *}$ & $-0.00425^{* * *}$ \\
\hline & $(-3.43)$ & $(-2.80)$ & $(-4.56)$ \\
\hline \multirow{2}{*}{ Dperda $_{i t}$} & 0.0133 & 0.0133 & $0.0101^{* * *}$ \\
\hline & $(1.21)$ & $(0.82)$ & $(3.57)$ \\
\hline \multirow{2}{*}{$R O A_{i t}$} & $0.691^{* * *}$ & $0.691^{* * *}$ & $0.884^{* * *}$ \\
\hline & $(15.98)$ & $(4.32)$ & $(41.67)$ \\
\hline \multirow{2}{*}{ Alafin $_{i t}$} & -0.000286 & -0.000286 & $-0.000589^{* *}$ \\
\hline & $(-0.26)$ & $(-0.65)$ & $(-2.52)$ \\
\hline \multirow{2}{*}{$\mathrm{FCO}_{i t}$} & $-0.530^{* * *}$ & $-0.530^{*}$ & $-0.297^{* * *}$ \\
\hline & $(-13.00)$ & $(-1.92)$ & $(-15.11)$ \\
\hline
\end{tabular}

Note: References (1)/(2)/(3) in the column headings indicate the simulated econometric models, being: (1) Pooled OLS regression model; (2) Polled OLS with Heteroskedasticity-Robust Inference Estimator; and (3) Polled OLS with Generalized Least Squares (GLS) Estimator; Varniit = variation in net profit of firm $i$ from year $t-1$ to year $t$, weighted by total assets at the beginning of year $t$; Varni ${ }_{i t-1}=$ variation in net profit of firm $i$ from year $t-2$ to year $t-1$, weighted by total assets at the beginning of year $t-1$; $D_{\text {varni }}{ }_{i t-1}=$ dummy variable that indicates whether there is a negative variation in the net profit of firm $i$ from year $t-1$ to year $t$, assuming a value of 1 (one) if Varni ${ }_{i t}<0$, or 0 (zero) otherwise; LnAtivo $_{i t}=$ logarithm of total assets of firm $i$ in year $t$; $R O A_{i t}=$ return on assets of firm $i$ in year $t$; Dperda $a_{i t}=$ dummy variable that indicates whether the net profit of firm $i$ in year $t$ was negative,

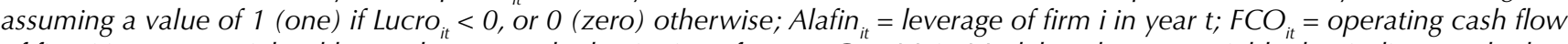

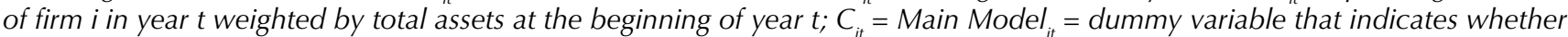
firm $i$ was mentioned in a corruption crime investigation in year $t$, in which it assumes a value of 1 (one), or 0 (zero) otherwise; $C_{i t}=$ Crisis $_{\text {Model }}=$ dummy variable indicating whether year $t$ is a year of crisis, in which it assumes a value of 1 (one), or 0 (zero) otherwise.

*,** and ${ }^{* * *}$ indicate the significance level of $10 \%, 5 \%$ and $1 \%$, respectively.

Source: Prepared by the authors. 


\begin{tabular}{|c|c|c|c|}
\hline \multirow{2}{*}{ Varni $_{i t}$} & \multicolumn{3}{|c|}{ CRISIS MODEL } \\
\hline & ( 1 ) & (2) & ( 3 ) \\
\hline \multirow{2}{*}{ Constante $\left(\alpha_{0}\right)$} & $0.188^{* * *}$ & $0.188^{* * *}$ & $0.0535^{* * *}$ \\
\hline & (4.39) & (3.57) & $(2.66)$ \\
\hline \multirow{2}{*}{$\operatorname{Dvarni}_{i t-1}\left(\alpha_{1}\right)$} & $0.0253^{* *}$ & $0.0253^{* *}$ & $0.00701^{* * *}$ \\
\hline & $(2.34)$ & $(2.33)$ & (3.33) \\
\hline \multirow{2}{*}{$\operatorname{Varn}_{i t-1}\left(\alpha_{2}\right)$} & $-0.645^{* * *}$ & $-0.645^{* * *}$ & $-0.533^{* * *}$ \\
\hline & $(-54.44)$ & $(-37.06)$ & $(-17.49)$ \\
\hline \multirow{2}{*}{$\operatorname{Dvarni}_{i t-1}{ }^{*} \operatorname{Varni}_{i t-1}\left(\alpha_{3}\right)$} & $0.524^{* * *}$ & $0.524^{* * *}$ & $0.186^{* * *}$ \\
\hline & $(26.45)$ & $(9.63)$ & (3.69) \\
\hline \multirow{2}{*}{$C_{i t}\left(\alpha_{4}\right)$} & -0.0152 & -0.0152 & $-0.00987^{* *}$ \\
\hline & $(-0.72)$ & $(-1.06)$ & $(-2.31)$ \\
\hline \multirow{2}{*}{$C_{i t}^{*} \operatorname{Dvarni}_{i t-1}\left(\alpha_{5}\right)$} & 0.00129 & 0.00129 & 0.00574 \\
\hline & $(0.05)$ & $(0.07)$ & $(1.23)$ \\
\hline \multirow{2}{*}{$C_{i t}^{*} \operatorname{Varni}_{i t-1}\left(\alpha_{6}\right)$} & $0.262^{* * *}$ & $0.262^{* * *}$ & $0.234^{* * *}$ \\
\hline & (12.10) & (11.43) & $(4.44)$ \\
\hline \multirow{2}{*}{$C_{i t}^{*} \operatorname{Dvarni}_{i t-1} * \operatorname{Varni}_{i t-1}\left(\alpha_{7}\right)$} & $-0.291 * * *$ & $-0.291^{* *}$ & $-0.459^{* * *}$ \\
\hline & $(-5.65)$ & $(-2.02)$ & $(-4.53)$ \\
\hline \multirow{2}{*}{$\operatorname{Ln}_{\text {Ativo }_{i t}}$} & $-0.0138^{* * *}$ & $-0.0138^{* * *}$ & $-0.00599 * * *$ \\
\hline & $(-4.87)$ & $(-3.76)$ & $(-4.45)$ \\
\hline \multirow{2}{*}{ Dperda $_{i t}$} & 0.0118 & 0.0118 & 0.0000755 \\
\hline & $(0.91)$ & $(0.71)$ & $(0.03)$ \\
\hline \multirow{2}{*}{$R O A_{i t}$} & $0.731^{* * *}$ & $0.731^{* * *}$ & $0.862^{* * *}$ \\
\hline & (15.66) & $(5.48)$ & (33.90) \\
\hline \multirow{2}{*}{ Alafin $_{i t}$} & -0.0000604 & -0.0000604 & -0.0000224 \\
\hline & $(-0.55)$ & $(-1.06)$ & $(-0.99)$ \\
\hline \multirow{2}{*}{$F C O_{i t}$} & $-0.463^{* * *}$ & $-0.463^{* *}$ & $-0.155^{* * *}$ \\
\hline & $(-9.74)$ & $(-2.03)$ & $(-8.30)$ \\
\hline \multirow{2}{*}{ AnoCrise $_{i t}$} & $0.0303^{*}$ & $0.0303^{* *}$ & $0.0242^{* * *}$ \\
\hline & $(1.70)$ & $(2.04)$ & (5.88) \\
\hline
\end{tabular}

Note: References (1)/(2)/(3) in the column headings indicate the simulated econometric models, being: (1) Pooled OLS regression model; (2) Polled OLS with Heteroskedasticity-Robust Inference Estimator; and (3) Polled OLS with Generalized Least Squares (GLS) Estimator; Varni ${ }_{i t}=$ variation in net profit of firm i from year $t-1$ to year $t$, weighted by total assets at the beginning of year $t$; Varni $_{i t-1}=$ variation in net profit of firm $i$ from year $t-2$ to year $t-1$, weighted by total assets at the beginning of year $t-1$; Dvarni $_{i t-1}=$ dummy variable that indicates whether there is a negative variation in the net profit of firm $i$ from year $t-1$ to year $t$, assuming a value of 1 (one) if Varni $i_{i t}<0$, or 0 (zero) otherwise; Ln Ativo $_{i t}=$ logarithm of total assets of firm i in year $t$; $R O A_{i t}=$ return on assets of firm $i$ in year $t$; Dperda $a_{i t}=$ dummy variable that indicates whether the net profit of firm $i$ in year $t$ was negative,

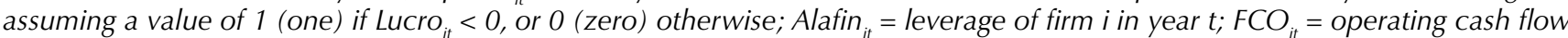

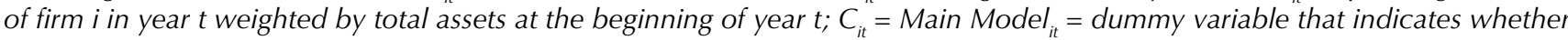
firm $i$ was mentioned in a corruption crime investigation in year $t$, in which it assumes a value of 1 (one), or 0 (zero) otherwise; $C_{i t}=$ Crisis Model $_{i t}=$ dummy variable indicating whether year $t$ is a year of crisis, in which it assumes a value of 1 (one), or 0 (zero) otherwise.

*,** and *** indicate the significance level of $10 \%, 5 \%$ and $1 \%$, respectively.

Source: Prepared by the authors 